\title{
PERFORMANCE OF SOYBEANS WITH THE APPLICATION OF GLYPHOSATE FORMULATIONS IN BIOSTIMULANT ASSOCIATION ${ }^{1}$
}

\author{
CHRISTIANO LIMA LOBO DE ANDRADE ${ }^{2 *}$, ALESSANDRO GUERRA DA SILVA ${ }^{3}$, GUILHERME BRAGA \\ PEREIRA BRAZ ${ }^{3}$, RUBEM SILVÉRIO DE OLIVEIRA JÚNIOR ${ }^{4}$, GUSTAVO ANDRÉ SIMON ${ }^{3}$
}

\begin{abstract}
Glyphosate is the main herbicide used in the Roundup Ready ${ }^{\circledR}\left(R^{\circledR}\right)$ soybean crop. However, the different salt and herbicide formulations available on the market can lead to crop intoxication. In this scenario, biostimulants appear as a promising alternative to mitigate the possible phytotoxic effects of glyphosate. Thus, the objective of this work was to evaluate the effects of different MC Extra ${ }^{\circledR}$ biostimulant doses associated with glyphosate formulations on the agronomic characteristics of a herbicide-tolerant soybean cultivar. Two experiments were conducted in the 2015/16 and 2016/17 seasons with three doses of MC Extra ${ }^{\circledR}$ $\left(0.35,0.70\right.$, and $\left.1.00 \mathrm{~kg} \mathrm{ha}^{-1}\right)$ associated with six formulations of glyphosate: Glyphotal ${ }^{\circledR}$, Roundup Original ${ }^{\circledR}$, Roundup Ready ${ }^{\circledR}$, Roundup $\mathrm{WG}^{\circledR}$, Roundup Transorb ${ }^{\circledR}$, and Zapp QI ${ }^{\circledR}$, plus additional treatment without the use of the herbicide. In both experiments, we used $900 \mathrm{~g}$ e.a. $\mathrm{ha}^{-1}$ of glyphosate. The results showed that the highest dose of MC Extra ${ }^{\circledR}$, in combination with the Roundup Original ${ }^{\circledR}$, Roundup Ready ${ }^{\circledR}$, and Roundup Transorb $^{\circledR}$ formulations and $0,70 \mathrm{~kg} \mathrm{ha}^{-1}$ of MC Extra ${ }^{\circledR}$ with Glyphotal ${ }^{\circledR}$ provided the highest grain yields. When used in conjunction with the herbicide, there is a need to increase the dose of MC Extra ${ }^{\circledR}$ to obtain higher soybean yields.
\end{abstract}

Keywords: Algae extract. Ascophyllum nodosum. Glycine max. Herbicides. Productivity.

\section{DESEMPENHO DA SOJA SUBMETIDA A APLICAÇÃO DE FORMULAÇÕES DE GLYPHOSATE EM ASSOCIAÇÃO COM BIOESTIMULANTE}

RESUMO - O glyphosate é o principal herbicida utilizado no controle de plantas daninhas na cultura da soja Roundup Ready ${ }^{\circledR}\left(\mathrm{RR}^{\circledR}\right)$, entretanto os diferentes sais e formulações do herbicida disponíveis no mercado podem ocasionar fitointoxicação. Neste cenário, os bioestimulantes surgem como alternativa promissora para mitigar os possíveis efeitos fitotóxicos do glyphosate. Sendo assim, objetivo do trabalho foi avaliar o efeito de doses do bioestimulante MC Extra ${ }^{\circledR}$ associado as formulações de glyphosate nas características agronômicas da cultura da soja tolerante ao herbicida. Conduziram-se dois experimentos nas safras 2015/16 e 2016/17 adotando -se três doses do MC Extra ${ }^{\circledR}\left(0.35 ; 0.70\right.$ e $\left.1.00 \mathrm{~kg} \mathrm{ha}^{-1}\right)$ associadas a seis formulações de glyphosate: Glyphotal $^{\circledR}$, Roundup Original ${ }^{\circledR}$, Roundup Ready ${ }^{\circledR}$, Roundup $\mathrm{WG}^{\circledR}$, Roundup Transorb ${ }^{\circledR}$ e Zapp QI ${ }^{\mathbb{R}}$, além de um tratamento adicional sem o uso do herbicida. Em ambos os experimentos foi padronizado o uso da dose de 900 g e. a. ha ${ }^{-1}$ de glyphosate. Os resultados demonstraram que a maior dose do MC Extra ${ }^{\circledR}$, em associação às formulações Roundup Original $^{\circledR}$, Roundup Ready ${ }^{\circledR}$ e Roundup Transorb ${ }^{\circledR}$ e $0.70 \mathrm{~kg} \mathrm{ha}^{-1}$ de MC Extra ${ }^{\circledR}$ com Glyphotal $^{\circledR}$ foram as que proporcionaram as maiores produtividades de grãos. Quando usado em conjunto com o herbicida, há a necessidade de aumento da dose do $\mathrm{MC} \mathrm{Extra}^{\circledR}$ para se ter maiores produtividades de grãos da soja.

Palavras-chave: Extrato de algas. Ascophyllum nodosum. Glycine max. Herbicidas. Produtividade de grãos.

\footnotetext{
"Corresponding author

${ }^{1}$ Received for publication in $06 / 21 / 2019$; accepted in $03 / 05 / 2020$.

Paper extracted from the master's dissertation of the first author.

${ }^{2}$ Department of Agricultural Sciences, Instituto Federal Goiano, Rio Verde, GO, Brazil; christiano.instrutoria@gmail.com - ORCID: 00000002-6743-3666.

${ }^{3}$ Department of Agricultural Sciences, Universidade de Rio Verde, Rio Verde, GO, Brazil; silvaag@yahoo.com - ORCID: 0000-0002-9556 -0312, guilhermebrag@gmail.com - ORCID: 0000-0002-0396-7140, simon@unirv.edu.br - ORCID: 0000-0001-6935-6580.

${ }^{4}$ Department of Agricultural Sciences, Universidade Estadual de Maringá, Maringá, PR, Brazil; rubem.oliveirajr@gmail.com - ORCID: 0000-0002-5222-8010.
} 


\section{INTRODUCTION}

Brazil stands out as a major producer of soybeans, with prospects for the coming years to take the lead in the world ranking of this oilseed. Among the factors that contributed to the growth of the soy complex, we highlight the implementation of the Roundup Ready ${ }^{\circledR}$ (RRß) technology, a glyphosate-tolerant soybean cultivar (OSIPE et al., 2014; BOMTEMPO, 2016). This made it possible to rotate a molecule with a broad spectrum of action, which allowed for increased efficiency in weed control, besides reducing the injuries caused by the latifolicides traditionally used in conventional soy cultivation (ZOBIOLE; KREMER; CONSTANTIN, 2012; MEROTTO JR; WAGNER; MENEGUZZI, 2015). Additionally, this technology also contributed to the consolidation of the no-till system in the country.

However, the application of glyphosate in plants that contain the herbicide tolerance gene can alter physiological plant processes (COBB; READE, 2010; CARVALHO, 2013). When ionized, glyphosate takes the form of a phosphonic anion, a conformation that promotes the immobilization of biand trivalent cations (VRIES; FEHR, 2011; BINSFELD et al., 2014). Additionally, glyphosate biodegradation results in the accumulation of aminomethylphosphonic acid (COBB; READE, 2010), a toxic compound that compromises the functioning of important metabolic routes, reducing the synthesis of secondary metabolites (MACKINNON et al., 2010; VRIES; FEHR, 2011). This, in turn, promotes a reduction in the accumulation of biomass, compromising plant growth and development (MACKINNON et al., 2010).

One of the compromised metabolic routes, that of chiquimic acid, is responsible for the synthesis of aromatic amino acids, which are precursors to the synthesis of auxins and gibberellins (COBB; READE, 2010). Blocking the route of chiquimic acid may imply a lower capacity for plants to overcome the stress imposed on the physiological apparatus (MEROTTO JR; WAGNER; MENEGUZZI, 2015), causing less accumulation of plant biomass. Concomitantly, glyphosate can compromise the gas exchange process with a reduction in liquid photosynthesis (ANDRADE et al., 2018), which can lead to a decrease in crop grain yield.

Another factor that determines the phytotoxic potential of glyphosate is the availability of formulations, with emphasis on isopropylamine, ammonium, and potassium salts in addition to the association between isopropylamine and potassium salts (AGROFIT, 2012). Depending on the raw material used in the formulation, adjuvants are defined to guarantee the solubility and physical stability of the active ingredient in the mixture. Given this, the formulation of the herbicide can influence the behavior of the molecule in mixture with other products and the membrane permeability (VIEIRA et al., 2018), interfering with the penetration of the molecule in the cuticle and its absorption by cells.

To prevent possible toxic effects caused by glyphosate formulations, it has been proposed to use biostimulants derived from the seaweed Ascophyllum nodosum (CRAIGIE, 2011; ANDRADE et al., 2018). This species contains plant hormones, amino acids, polysaccharides, and fatty acids, in addition to macro- and micronutrients (WALLY et al., 2013; SHARMA et al., 2014; POVERO et al., 2016). These compounds in plants optimize chemical signals, in addition to benefiting enzymatic activities, thereby enhancing the metabolic performance of plants (TANDON; DUBEY, 2015; VAN OOSTEN et al., 2017).

Research work carried out by Andrade et al. (2018) shows that the use of the biostimulant derived from $A$. nodosum, MC Extra ${ }^{\circledR}$, associated with glyphosate, provided $11 \%$ increments in grain productivity. Due to the complexity and the difficulty of determining the components contained in biostimulants and responsible for the positive contributions in plants (DU JARDIN, 2015; VAN OOSTEN et al., 2017), mainly when associated with glyphosate (ANDRADE et al., 2018), it is necessary to evaluate its behavior in association with different commercial formulations of the herbicide in question.

Based on the above, it is expected that applications of different commercial formulations of glyphosate in Roundup Ready ${ }^{\circledR}\left(\mathrm{RR}^{\circledR}\right)$ soybeans can have negative effects on the plant's metabolism, thus compromising the development and productivity of the crop. On the other hand, it is believed that $\mathrm{MC}$ Extra $^{\circledR}$, due to its composition, can be considered a strategy to mitigate the harmful effects on soy plants.

In view of this, this work aimed to evaluate the effects of doses of the biostimulant based on Ascophylium nodosum, called MC Extra ${ }^{\circledR}$, associated with glyphosate formulations, on the agronomic characteristics of soybean crops.

\section{MATERIAL AND METHODS}

The experiments were conducted in the field in the 2015/16 and 2016/17 harvests in the municipality of Montividiu-GO (17 $31^{\prime} 04.5^{\prime \prime} \mathrm{S}$; $51^{\circ}$ $12^{\prime} 55.8^{\prime \prime} \mathrm{O}$, at $890 \mathrm{~m}$ above sea level; 17³1'19.64”'S; $51^{\circ} 13 ' 22.43$ "O, at $894 \mathrm{~m}$ above sea level, respectively), in areas with soil cultivated using the no-tillage system. Precipitation and average air temperature data during the conduction of the experiments are shown in (Figure 1). 


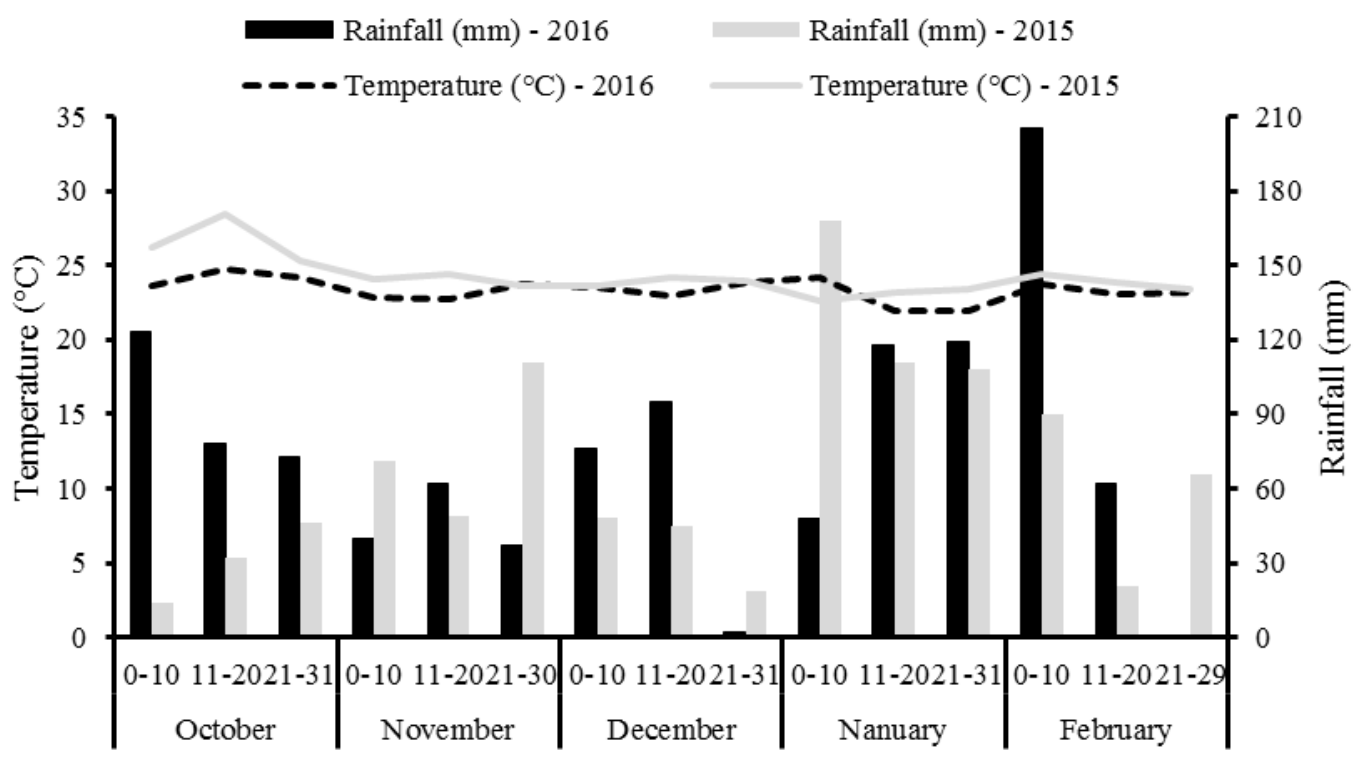

Figure 1. Rainfall $(\mathrm{mm})$ and average air temperature $\left({ }^{\circ} \mathrm{C}\right)$ values during the experiments.

The soil samples from the experimental area were collected from the $0-20$-cm soil layer. In the $2015 / 16$ harvest, the physical and chemical characteristics were as follows: $\mathrm{pH}$ in $\mathrm{CaCl}_{2}: 5.3 ; \mathrm{Ca}$, $\mathrm{Mg}, \mathrm{K}, \mathrm{Al}, \mathrm{H}+\mathrm{Al}, \mathrm{SB}$, and CTC: $3.0 ; 0.7 ; 0.3 ; 0.1$; 4.0; 4.0, and 8.0 in $\mathrm{cmol}_{\mathrm{c}} \mathrm{dm}^{-3}$, P: $3.6 \mathrm{mg} \mathrm{dm}^{-3}$; MO: $30.1 \mathrm{~g} \mathrm{~kg}^{-1} ; \mathrm{m}: 1.4 \%$; V: $50.5 \%$, sand, silt, and clay: $61 ; 7$ and $32 \%$, respectively (clay-sandy loam). In the following harvest, the results of the soil analysis were as follows: $\mathrm{pH}$ in $\mathrm{CaCl}_{2}: 4.5 ; \mathrm{Ca}, \mathrm{Mg}, \mathrm{K}, \mathrm{Al}, \mathrm{H}$ $+\mathrm{Al}$, SB and CTC: $1.2 ; 0.26 ; 0.23 ; 0.22 ; 3.56 ; 1.59$,

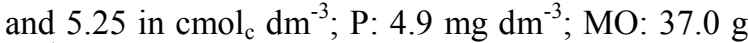
$\mathrm{kg}^{-1} ; \mathrm{m}: 11.5 \%$; V: $31.2 \%$, sand, silt, and clay: $60 ; 8$ e $32 \%$, respectively (clay-sandy loam).

In the $2015 / 16$ crop, the $3 \times 7+1$ factorial arrangement was adopted for three doses of the MC Extra $^{\circledR}$ biostimulant $\left(0.35 ; 0.70\right.$, and $\left.1.00 \mathrm{~kg} \mathrm{ha}^{-1}\right)$ associated with six glyphosate formulations (1Glyphotal $^{\circledR}$, isopropylamine salt, $648 \mathrm{~g} \mathrm{~L}^{-1}$; 2Roundup Original $^{\circledR}$, isopropylamine salt, $480 \mathrm{~g} \mathrm{~L}^{-1} ; 3$ -Roundup Ready ${ }^{\circledR}$, isopropylamine salt, $648 \mathrm{~g} \mathrm{~L}^{-1}$; 4Roundup $\mathrm{WG}^{\circledR}$, ammonium salt, $791.5 \mathrm{~g} \mathrm{~kg}^{-1}$; 5Roundup Transorb ${ }^{\circledR}$, potassium salt, $580 \mathrm{~g} \mathrm{~L}^{-1} ; 6$ Zapp QI ${ }^{\circledR}$, potassium salt, $620 \mathrm{~g} \mathrm{~L}^{-1}$; and 7Treatment without herbicide application). The additional treatment consisted of the absence of herbicide and biostimulant application (Control).

In the second year, the experiment was installed in a 4 x 7 factorial arrangement, corresponding to four doses of MC Extra ${ }^{\circledR}(0.00$, $0.35,0.70$, and $1.00 \mathrm{~kg} \mathrm{c.p.} \mathrm{ha}{ }^{-1}$ ), associated with six glyphosate formulations, the same employed in the first experiment, plus one treatment without herbicide. In this trial, to verify the repair effect of the biostimulant, the treatment without the application of glyphosate and biostimulant was considered the absolute witness.

The MC Extra ${ }^{\circledR}$ biostimulant is derived from the algal species Ascophyllum nodosum, consisting of organic carbon $\left(200 \mathrm{~g} \mathrm{~L}^{-1}\right)$, nitrogen, and potassium (10 and $200 \mathrm{~g} \mathrm{~L}^{-1}$, respectively). In both experiments, the application of $900 \mathrm{~g} \mathrm{e}$. a. $\mathrm{ha}^{-1}$ of glyphosate for all formulations was evaluated, as this is the recommended dose for the control of most weed species in soybean crops (AGROFIT, 2012). The experimental units contained six lines with a length of $5.0 \mathrm{~m}$ in length, spaced $0.5 \mathrm{~m}$ apart. The usable area was obtained taking into account the two central lines, disregarding $0.5 \mathrm{~m}$ from each end, thus representing $4.0 \mathrm{~m}^{2}$.

When applying the treatments, MC Extra ${ }^{\circledR}$ was associated with the respective glyphosate formulations in the same application solution, adding the herbicide first and then MC Extra ${ }^{\circledR}$, with subsequent homogenization of the solution. The applications were carried out with a $\mathrm{CO}_{2}$ sprayer pressurized by $\mathrm{CO}_{2}$, equipped with a TT 110-02 sixtip bar, with double fan and a spray volume equivalent to $150 \mathrm{~L} \mathrm{ha}^{-1}$ when set at $1.5 \mathrm{kgf} \mathrm{cm}^{-2}$, at a speed of $1.0 \mathrm{~m} \mathrm{~s}^{-1}$. For the 2015/16 and 2016/17 harvests, the climatic data at the time of application $(12 / 04$ at $14: 15 \mathrm{~h}$; and $19 / 11$ at $15: 35 \mathrm{~h})$ were, 
respectively: wind speed: 3.9 and $1.0 \mathrm{~km} \mathrm{~h}^{-1}$; temperature: 33.3 and $27.8^{\circ} \mathrm{C}$, and relative humidity: 56.0 and $51.8 \%$. On those dates, the plants had seven and four fully developed trifoliate leaves, respectively.

In both experiments, fertilization was carried out by hauling 1 month prior to soybean sowing; 510 and $375 \mathrm{~kg} \mathrm{ha}^{-1}$ of simple superphosphate were used for the 2015/16 and 2016/17 harvests, respectively, in addition to $150 \mathrm{~kg} \mathrm{ha}^{-1}$ of potassium chloride, for both harvests. In the 2016/17 harvest, due to the low magnesium content in the soil, an additional application, also 1 month prior to sowing, of $220 \mathrm{~kg}$ ha- ${ }^{1}$ of magnesium sulfate was carried out. Weed desiccation was performed prior to sowing soybeans with mechanically applied 900 g e. a. ha-1de glyphosate.

Soybeans were sown on October 29 and 21, 2015 and 2016, respectively, with distribution of 18 seeds per linear meter in both harvests. We used the cultivar TMG 7062 IPRO $^{\circledR}$, which is characterized by semi-determined growth, maturation group 6.2 for the region of the experiment, an early cycle, white flowers, and gray pubescence. In all groups, crop treatments were carried out according to the needs of the crop to avoid problems with pests and diseases, ensuring that these factors do not interfere with the development and productivity of soybeans.

In the 2015/16 crop, it was necessary to apply glyphosate $\left(1160 \mathrm{~g}\right.$ e. a. $\left.\mathrm{Ha}^{-1}\right) 23$ days after emergence (DAE) as a weed management practice in the experimental area. Despite this, it is noteworthy that all experimental units were weeded throughout the soybean cycle in both experiments to eliminate the effect of the weed community's interference on crop productivity. In this way, the plants were exposed only to the effect of the herbicides combined with the effects of the doses of the biostimulant.

At 10 days after application of treatments (DAA) (corresponding to 41 and 34 DAE for the 2015/16 and 2016/17 harvests, respectively), a vigor assessment was carried out in the useful area of the plots through visual observation of plant development. A scale of grades from 1 to 5, performed by three evaluators, was used: 1: much lower; 2: lower; 3: equal; 4: upper; and 5: much higher than the witness (SILVA et al., 2016).
The harvests were carried out on February 11 and 16, 2016 and 2017 (98 and 110 DAE, respectively), with the following evaluations in the useful plot area: grain yield (harvesting of the plants with pod threshing and weighing of the grains with humidity correction to $13 \%$, with later conversion of results to $\mathrm{kg} \mathrm{ha}^{-1}$ ); thousand-grain-weight (weighing 1,000 grains from the productivity sample, with humidity correction to $13 \%$ ); number of grains per plant (counting the number of grains per plant based on the evaluation of five plants collected at random); plant population (counting the number of plants, extrapolating the results per hectare); plant height (measurement of the neck to the end of the insertion of the last trifoliate leaf completely developed in five plants collected at random), and insertion of the first pod (measurement of the neck to the insertion of the first pod in five plants collected at random).

The data were subjected to analysis of variance $(p \leq 0.05)$ for interaction between factors. When significance was found, the Scott-Knott test was used to compare the averages of the glyphosate formulations and regression analysis to compare the doses of MC Extra ${ }^{\circledR}$ ( $\left.p \leq 0.05\right)$, either due to the average effect or the significant interaction between the sources of variation tested. To verify the relationships between the analyzed variables, Pearson's linear correlation coefficient at $5 \%$ probability was determined. In addition to these analyses for the first experiment, depending on the experimental arrangement, the Dunnett test ( $\mathrm{p} \leq$ 0.05 ) was used to compare the treatment means with the absolute control, as previously described.

\section{RESULTS AND DISCUSSION}

Based on the results obtained for the 2015/16 crop, an isolated effect of MC Extra ${ }^{\circledR}$ doses for grain yield was found (Table 1). All doses of the biostimulant provided lower productivity than the control; however, increases in the values of the response variable would be obtained only for a dose of $0.62 \mathrm{~kg} \mathrm{ha}^{-1}$ (Figure 2). The only treatment with a higher value than the control was the one with the highest dose of MC Extra ${ }^{\circledR}$ without the association of glyphosate. 
Table 1. Summary of the analysis of variance of productivity (PROD) and thousand-grain-weight (PMG), number of grains per plant (NGP), population (POP), plant height (AP), insertion of the first pod (AIV), and vigor (VIG) of the experiment to apply the MC Extra ${ }^{\mathrm{B}}$ biostimulant associated with glyphosate formulations in a soybean culture

\begin{tabular}{lcccccccc}
\hline \multicolumn{1}{c}{ Source of variation } & DG & PROD & PMG & NGP & POP & AP & AIV & VIG \\
\hline & & & & $2015 / 16$ Harvest & & & & $*$ \\
Blocks (B) & 3 & $\mathrm{~ns}$ & $\mathrm{~ns}$ & $\mathrm{~ns}$ & $\mathrm{~ns}$ & $* *$ & $*$ & $\mathrm{~ns}$ \\
Doses (D) & 2 & $* *$ & $\mathrm{~ns}$ & $* *$ & $\mathrm{~ns}$ & $\mathrm{~ns}$ & $* *$ & $* *$ \\
Formulations (F) & 6 & $\mathrm{~ns}$ & $\mathrm{~ns}$ & $\mathrm{~ns}$ & $\mathrm{~ns}$ & $* *$ & $* *$ & $* *$ \\
D x F & 12 & $\mathrm{~ns}$ & $\mathrm{~ns}$ & $\mathrm{~ns}$ & $\mathrm{~ns}$ & $\mathrm{~ns}$ & $\mathrm{~ns}$ & $\mathrm{~ns}$ \\
Factorial x Witness & 1 & $\mathrm{~ns}$ & $\mathrm{~ns}$ & $\mathrm{~ns}$ & $\mathrm{~ns}$ & $\mathrm{~ns}$ & $\mathrm{~ns}$ & $\mathrm{~ns}$ \\
CV (\%) & - & 5.6 & 4.8 & 8.7 & 7.2 & 6.1 & 17.9 & 13.3 \\
\hline & & & & $2016 / 17$ Harvest & & & & \\
Blocks (B) & 3 & $\mathrm{~ns}$ & $\mathrm{~ns}$ & $\mathrm{~ns}$ & $\mathrm{~ns}$ & $\mathrm{~ns}$ & $\mathrm{~ns}$ & $*$ \\
Doses (D) & 3 & $\mathrm{~ns}$ & $\mathrm{~ns}$ & $\mathrm{~ns}$ & $*$ & $*$ & $\mathrm{~ns}$ & $\mathrm{~ns}$ \\
Formulations (F) & 6 & $\mathrm{~ns}$ & $\mathrm{~ns}$ & $\mathrm{~ns}$ & $*$ & $\mathrm{~ns}$ & $\mathrm{~ns}$ & $\mathrm{~ns}$ \\
D x F & 18 & $* *$ & $*$ & $\mathrm{~ns}$ & $\mathrm{~ns}$ & $* *$ & $\mathrm{~ns}$ & $\mathrm{~ns}$ \\
CV (\%) & - & 6.5 & 2.7 & 12.5 & 9.6 & 4.7 & 7.0 & 21.0 \\
\hline
\end{tabular}

DG: Degrees of freedom; CV: Coefficient of variation. *, **, ns: Significant at 1 and $5 \%$ probability and not significant, respectively, by the $\mathrm{F}$ test. A comparison of means for the Block factor was not performed.

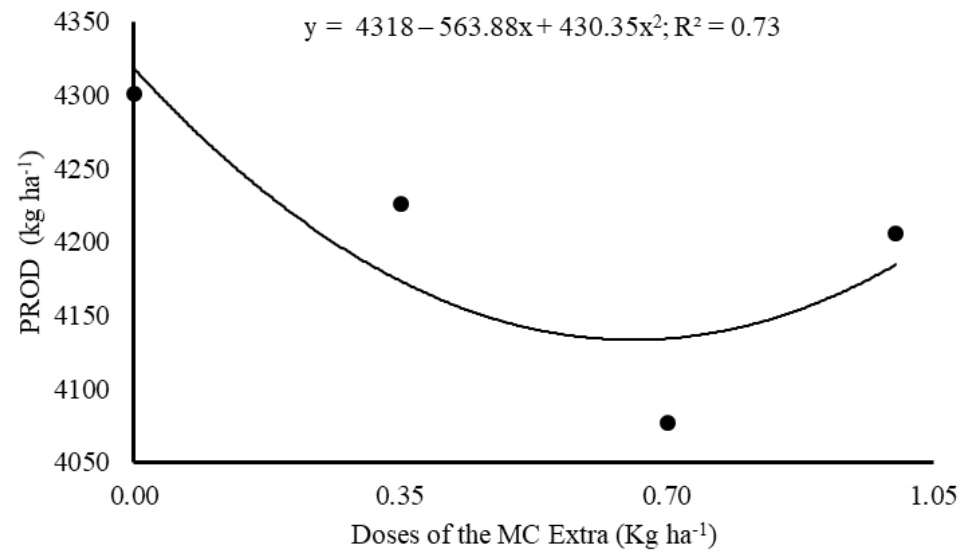

Figure 2. Grain productivity (PROD) values as a function of the MC Extra ${ }^{\circledR}$ biostimulant doses in soybean (values make up the isolated effect of the treatments; each point represents the average of the glyphosate formulations evaluated).

It is important to note that in the first evaluation year, there was an additional application of glyphosate for weed management, 7 days prior to the application of the biostimulant. In this context, the control and treatments with MC Extra ${ }^{\circledR}$ alone received $1.160 \mathrm{~g}$ e. a. $\mathrm{ha}^{-1}$ of glyphosate, while the other treatments with the combined herbicide formulations received a dose equivalent to $2060 \mathrm{~g}$ e. a. glyphosate $\mathrm{ha}^{-1}$. In general, higher doses of the biostimulant tend to increase soybean grain yield, regardless of the glyphosate formulation.

Although the biostimulant did not increase soybean grain productivity in the $2015 / 16$ crop, its potential is well characterized. This statement is supported by the fact that doses of glyphosate greater than $1.440 \mathrm{~g}$ e.a. ha ${ }^{-1}$, even with the application of biostimulants containing amino acids, will cause an increase in chlorophyll fluorescence (MEROTTO JR; WAGNER; MENEGUZZI, 2015). As a consequence, there is a reduction in energy dissipation for the synthesis of ATP and NADPH (TAIZ et al., 2017). This will compromise the enzymatic activities of the Calvin cycle and, consequently, the accumulation of metabolites, as well as plant growth, thus causing reductions in productivity (MEROTTO JR; WAGNER; MENEGUZZI, 2015). Possibly, this is the fact that justifies the decrease in soybean productivity up to the dose of $0.62 \mathrm{~kg} \mathrm{ha}^{-1}$ of the biostimulant. Above this value, there were increases in the values due to the components present in the formulation of $\mathrm{MC}$ Extra ${ }^{\circledR}$, which has a repairing effect on the plant. However, this was limited by the sequential application of glyphosate in a 7 day interval.

In the 2016/17 harvest, there was a synergistic effect of MC Extra ${ }^{\circledR}$ with glyphosate formulations on soybean grain productivity. In this condition, the dose of $1.00 \mathrm{Kg} \mathrm{ha}^{-1}$, that is, the 
highest dose associated with the Roundup Original ${ }^{\circledR}$, Roundup Ready ${ }^{\circledR}$, Glyphotal $^{\circledR}$, Roundup Transorb ${ }^{\circledR}$, and Zapp $\mathrm{QI}^{\circledR}$ formulations, provided higher productivity than the treatment with $1.00 \mathrm{Kg} \mathrm{ha}^{-1}$ of biostimulant without glyphosate. On the other hand, treatment with $1.00 \mathrm{~kg} \mathrm{ha}^{-1}$ of MC Extra ${ }^{\circledR}$, applied by itself, provided grain yield similar to the treatment with Roundup $\mathrm{WG}^{\circledR}$ in the same dose as the biostimulant (Table 2). This leads us to infer that there is no beneficial effect of MC Extra ${ }^{\circledR}$ with the aforementioned glyphosate formulation. Due to the physical-chemical characteristics, WG formulations may be subject to less solubilization, causing manufacturers to use solvents with a high reaction capacity, in addition to specific adjuvants in their composition (MARTINS et al., 2009). Thus, it is suggested that these properties of the formulation have contributed to increasing the herbicidal effect and rendering the biostimulant inefficient in reversing the deleterious effects of Roundup $\mathrm{WG}^{\circledR}$.

Table 2. Average values of productivity (PROD) and thousand-grain-weight (PMG) of the experiment of applying the MC Extra ${ }^{\circledR}$ biostimulant with glyphosate formulations in a soybean culture.

\begin{tabular}{|c|c|c|c|c|c|}
\hline \multirow{2}{*}{ Glyphosate formulations } & \multicolumn{4}{|c|}{--- Doses MC Extra ${ }^{\circledR}\left(\mathrm{kg} \mathrm{ha}^{-1}\right)$--- } & \multirow{2}{*}{ Means } \\
\hline & 0.00 & 0.35 & 0.70 & 1.00 & \\
\hline \multicolumn{6}{|c|}{--- PROD $\left(\mathrm{kg} \mathrm{ha}^{-1}\right)$--- } \\
\hline & \multicolumn{4}{|c|}{ 2015/16 Harvest } & \\
\hline Roundup Original $^{\circledR}$ & -- & 4239 & 3927 & 4210 & 4169 \\
\hline Roundup Ready ${ }^{\circledR}$ & -- & 4354 & 4179 & 4288 & 4281 \\
\hline Glyphotal $^{\circledR}$ & -- & 4167 & 4073 & 4114 & 4164 \\
\hline Roundup Transorb $^{\circledR}$ & -- & 4157 & 3886 & 3939 & 4071 \\
\hline Roundup $\mathrm{WG}^{\circledR}$ & -- & 4117 & 4151 & 4235 & 4201 \\
\hline Zapp QI ${ }^{\circledR}$ & -- & 4288 & 4179 & 4235 & 4251 \\
\hline Non glyphosate treated & -- & 4260 & 4145 & 4419 & 4281 \\
\hline Witness & \multicolumn{5}{|c|}{4301} \\
\hline \multirow[t]{2}{*}{ Means } & -- & 4226 & 4077 & 4206 & 4203 \\
\hline & \multicolumn{4}{|c|}{ 2016/17 Harvest } & \\
\hline Roundup Original $^{\circledR}$ & $4428 \mathrm{a}$ & $4657 \mathrm{a}$ & $4860 \mathrm{a}$ & $5124 \mathrm{a}$ & 4767 \\
\hline Roundup Ready ${ }^{\circledR}$ & $4666 \mathrm{a}$ & $4288 \mathrm{a}$ & $4647 \mathrm{a}$ & $4819 \mathrm{a}$ & 4605 \\
\hline Glyphotal $^{\circledR}$ & $4674 \mathrm{a}$ & $4789 \mathrm{a}$ & $5107 \mathrm{a}$ & $4870 \mathrm{a}$ & 4860 \\
\hline Roundup Transorb $^{\circledR}$ & $5039 a$ & $4739 \mathrm{a}$ & $4456 \mathrm{a}$ & $5111 \mathrm{a}$ & 4836 \\
\hline Roundup $\mathrm{WG}^{\circledR}$ & $4768 \mathrm{a}$ & $4781 \mathrm{a}$ & $4711 \mathrm{a}$ & $4416 \mathrm{~b}$ & 4669 \\
\hline Zapp QI ${ }^{\circledR}$ & $4852 \mathrm{a}$ & $4679 \mathrm{a}$ & $4454 \mathrm{a}$ & $4802 \mathrm{a}$ & 4697 \\
\hline Non glyphosate treated & 4747 a & $4933 \mathrm{a}$ & $4755 \mathrm{a}$ & $4618 b$ & 4763 \\
\hline \multirow[t]{3}{*}{ Means } & 4739 & 4695 & 4713 & 4823 & 4742 \\
\hline & \multicolumn{4}{|c|}{--- PMG (g) --- } & \\
\hline & \multicolumn{4}{|c|}{ 2015/16 Harvest } & \\
\hline Roundup Original $^{\circledR}$ & --- & 188 & 186 & 192 & 189 \\
\hline Roundup Ready ${ }^{\circledR}$ & --- & 190 & 190 & 191 & 190 \\
\hline Glyphotal $^{\circledR}$ & --- & 183 & 192 & 188 & 188 \\
\hline Roundup Transorb $^{\circledR}$ & --- & 187 & 184 & 190 & 188 \\
\hline Roundup $\mathrm{WG}^{\circledR}$ & --- & 186 & 189 & 198 & 191 \\
\hline Zapp QI ${ }^{\circledR}$ & --- & 188 & 189 & 189 & 189 \\
\hline Non glyphosate treated & --- & 190 & 203 & 190 & 193 \\
\hline Witness & \multicolumn{5}{|c|}{191} \\
\hline \multirow[t]{2}{*}{ Means } & --- & 188 & 190 & 191 & 190 \\
\hline & \multicolumn{4}{|c|}{ 2016/17 Harvest } & \\
\hline Roundup Original $^{\circledR}$ & $197 \mathrm{a}$ & $195 \mathrm{a}$ & $203 \mathrm{a}$ & $200 \mathrm{a}$ & 198 \\
\hline Roundup Ready ${ }^{\circledR}$ & $195 \mathrm{a}$ & $198 \mathrm{a}$ & $197 \mathrm{a}$ & $196 \mathrm{~b}$ & 196 \\
\hline Glyphotal $^{\circledR}$ & $197 \mathrm{a}$ & $188 \mathrm{a}$ & $199 \mathrm{a}$ & $203 \mathrm{a}$ & 197 \\
\hline Roundup Transorb $^{\circledR}$ & $201 \mathrm{a}$ & $192 \mathrm{a}$ & $192 \mathrm{a}$ & $200 \mathrm{a}$ & 196 \\
\hline Roundup $\mathrm{WG}^{\circledR}$ & $197 \mathrm{a}$ & $193 \mathrm{a}$ & $198 \mathrm{a}$ & $193 \mathrm{~b}$ & 195 \\
\hline Zapp QI ${ }^{\circledR}$ & $197 \mathrm{a}$ & $198 \mathrm{a}$ & $194 \mathrm{a}$ & $191 \mathrm{~b}$ & 195 \\
\hline Non glyphosate treated & $201 \mathrm{a}$ & $199 \mathrm{a}$ & $195 \mathrm{a}$ & $196 \mathrm{~b}$ & 198 \\
\hline Means & 198 & 195 & 197 & 197 & 197 \\
\hline
\end{tabular}

Averages followed by the same letters within one column do not differ by the Scott-Knott test at 5\% probability.

*: Means differ from the control by the Dunnett test at $5 \%$ probability. 
The effect of MC Extra ${ }^{\circledR}$ on recovery from stress caused by the application of glyphosate can be seen in the 2016/17 harvest. In this harvest, increased doses of the biostimulant provided linear increases in grain yield when associated with Roundup Original ${ }^{\circledR}$ (Figure 3). For the Roundup Transorb ${ }^{\circledR}$ formulation, increases in productivity were obtained with doses greater than $0.51 \mathrm{~kg} \mathrm{ha}^{-1}$, and values higher than in the treatment without the biostimulant, for the formulation in question, were obtained with a dose of $0.99 \mathrm{~kg} \mathrm{ha}^{-1}$. This suggests that the highest dose of the biostimulant, without being associated with Roundup Transorb ${ }^{\circledR}$, provides a greater productivity response in soybean culture.

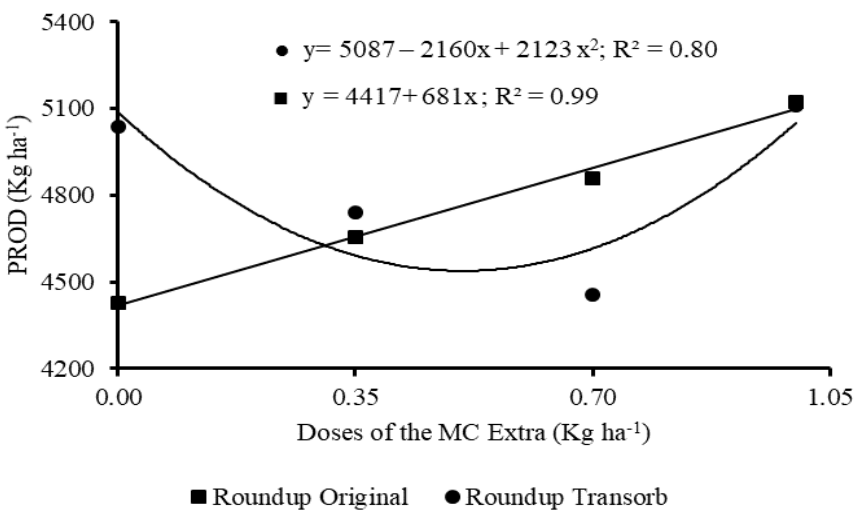

Figure 3. Grain yield (PROD) values as a function of $M C$ Extra ${ }^{\circledR}$ biostimulant doses associated with the Roundup Original $^{\circledR}$ and Transorb ${ }^{\circledR}$ formulations applied to a soybean culture.

The significant interaction verified for productivity in the $2016 / 17$ crop can be attributed to the effect of adjuvants, present in the formulations, on the leaf surface of soybean plants. This occurs because adjuvants promote adherence and rapid penetration of the herbicide into the cuticle (VELINI et al., 2012), allowing greater absorption by the epidermis cells (CARVALHO, 2013; PETTER et al., 2016). This benefits the absorption of the biostimulant in association with glyphosate (Roundup Ready ${ }^{\circledR}$ ), which has also been noted by Santos et al. (2015).

However, the changes caused to the leaf surface would still depend on the salt contained in the formulation of the herbicide and the concentration in acid equivalent (PINTO et al., 2016). This indicates that the choice of formulation may contribute to the disruption of the waxy leaf layer and to the leakage of electrolytes through the plasma membrane, benefiting the absorption of the biostimulant by soybean plants (PETTER et al., 2016; PINTO et al., 2016).

Thousand-grain-weight was not influenced by the action of the biostimulant and by the glyphosate formulations in the 2015/16 harvest (Table 1). In this case, applications were performed when the plants had seven fully developed trifoliate leaves and were close to the reproductive stage. Possibly, the sequential application of glyphosate caused immobilization of enzyme-activating elements such as copper, iron, zinc, and manganese. The reduction in the availability of these elements causes a reduction in the breakdown of water molecules in the photochemical phase of photosynthesis and a reduction in the synthesis of the rubisco enzyme, compromising the activities of the Calvin cycle (COBB; READE, 2010), which is responsible for carbon fixation and glucose synthesis; thus, compromising this metabolic route will cause reductions in the grain filling of soybean plants (COBB; READE, 2010; ZOBIOLE; KREMER; CONSTANTIN, 2012).

In the 2016/17 crop, there was an effect of glyphosate formulations on the variable thousand-grainweight. This effect was more evident in the higher dose of MC Extra ${ }^{\circledR}$, in which a higher grain weight was found when used in conjunction with the formulations Roundup Original ${ }^{\circledR}$, Glyphotal ${ }^{\circledR}$, and Roundup Transorb $^{\circledR}$ (Table 2). This contributed to obtaining higher grain yields. For Glyphotal ${ }^{\circledR}$ and Roundup Transorb ${ }^{\circledR}$, beneficial effects of the biostimulant on thousand-grainweight were obtained with higher doses of the product (Figure 4A). Due to the phenotypic plasticity of the TMG 7062 cultivar, the number of grains per plant, in the $2015 / 16$ harvest, was reduced to that of the dose of 0.79 $\mathrm{kg} \mathrm{ha}^{-1}$ of MC Extra ${ }^{\circledR}$, with increases in doses higher than this (Figure 4B). 

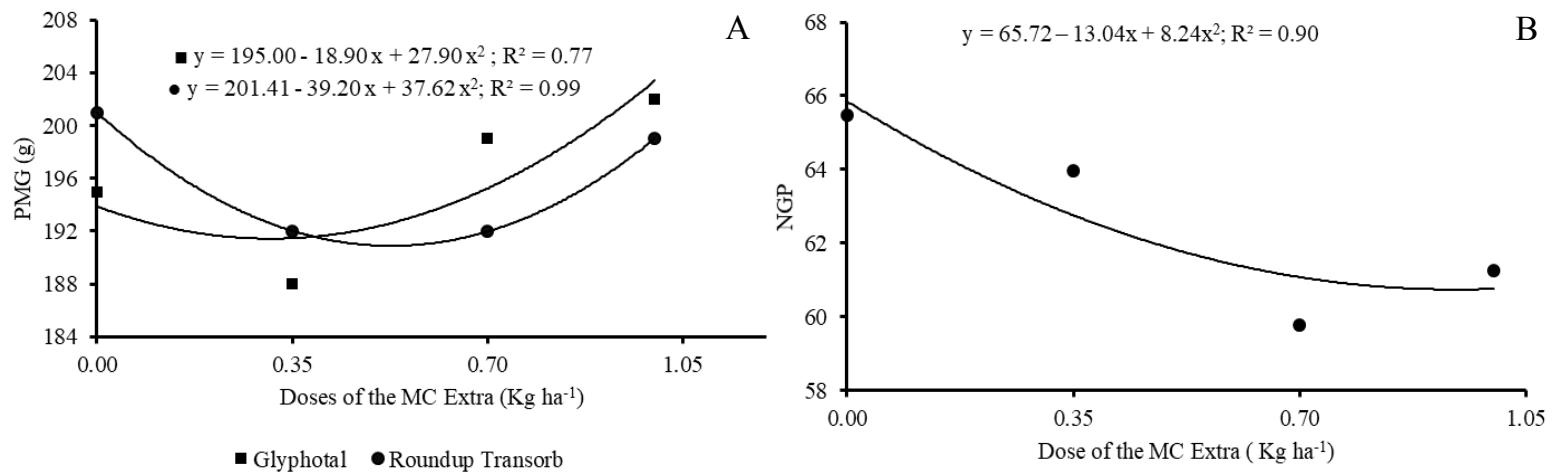

Figure 4. Unfolded weight values of 1,000 grains (PMG) and average number of grains per plant (NGP) in the 2016/17 (a) and 2015/16 (b) harvests, respectively, depending on the doses of MC Extra biostimulant ${ }^{\circledR}$ in a soybean culture.

It is important to note that, on average, the number of grains per plant in the 2016/17 harvest was $41 \%$ higher than that obtained in the previous harvest (Table 3), corroborating the difference in grain productivity. However, this difference is justified by the smaller plant population in the second harvest. This causes the plants to produce more grains per plant, as observed by Procópio et al. (2013) in a soybean cultivar with an indeterminate growth habit.

Table 3. Average values of number of grains per plant (NGP) and plant population (POP) when applying the MC Extra ${ }^{\circledR}$ biostimulant with glyphosate formulations to a soybean culture.

\begin{tabular}{|c|c|c|c|c|c|}
\hline \multirow{2}{*}{ Glyphosate formulations } & \multicolumn{4}{|c|}{--- Doses MC Extra ${ }^{\circledR}\left(\mathrm{kg} \mathrm{ha}^{-1}\right)$--- } & \multirow{2}{*}{ Means } \\
\hline & 0.00 & 0.35 & 0.70 & 1.00 & \\
\hline & \multicolumn{4}{|c|}{--- NGP --- } & \\
\hline & \multicolumn{4}{|c|}{ 2015/16 Harvest } & \\
\hline Roundup Original $^{\circledR}$ & -- & 63.3 & 59.4 & 63.1 & 62.8 \\
\hline Roundup Ready ${ }^{\circledR}$ & -- & 61.5 & 61.9 & 60.1 & 62.3 \\
\hline Glyphotal $^{\circledR}$ & -- & 63.2 & 60.0 & 62.7 & 62.9 \\
\hline Roundup Transorb $^{\circledR}$ & -- & 62.4 & 58.1 & 56.9 & 60.7 \\
\hline Roundup $\mathrm{WG}^{\mathbb{R}}$ & -- & 61.7 & 61.4 & 59.6 & 62.0 \\
\hline Zapp QI ${ }^{\circledR}$ & -- & 63.7 & 62.9 & 62.6 & 63.6 \\
\hline Non glyphosate treated & -- & 64.9 & 54.4 & 63.8 & 62.2 \\
\hline Witness & \multicolumn{5}{|c|}{65.4} \\
\hline \multirow[t]{2}{*}{ Means } & & 63.0 & 59.7 & 61.2 & 62.3 \\
\hline & \multicolumn{4}{|c|}{ 2016/17 Harvest } & \\
\hline Roundup Original $^{\circledR}$ & 101.7 & 107.0 & 106.3 & 104.3 & 104.6 \\
\hline Roundup Ready ${ }^{\circledR}$ & 108.0 & 108.6 & 117.5 & 99.8 & 108.5 \\
\hline Glyphotal $^{\circledR}$ & 110.7 & 113.7 & 115.0 & 98.1 & 109.4 \\
\hline Roundup Transorb $^{\circledR}$ & 105.8 & 97.2 & 107.5 & 111.9 & 105.6 \\
\hline Roundup $\mathrm{WG}^{\mathbb{R}}$ & 101.4 & 116.1 & 92.5 & 93.3 & 100.8 \\
\hline Zapp QI ${ }^{\circledR}$ & 111.0 & 93.3 & 92.9 & 102.1 & 101.9 \\
\hline Non glyphosate treated & 102.0 & 109.9 & 110.2 & 103.9 & 109.3 \\
\hline Means & 107.3 & 107.3 & 106.0 & 101.9 & 105.6 \\
\hline
\end{tabular}

Averages followed by the same letters within one column do not differ by the Scott-Knott test at 5\% probability.

*: Means differ from the control by the Dunnett test at $5 \%$ probability. 
Table 3. Continuation.

\begin{tabular}{|c|c|c|c|c|c|}
\hline \multirow[t]{2}{*}{ Glyphosate formulations } & \multicolumn{4}{|c|}{--- Doses MC Extra ${ }^{\circledR}(\mathrm{kg}$ ha-1) --- } & \multirow[t]{2}{*}{ Means } \\
\hline & 0.00 & 0.35 & 0.70 & 1.00 & \\
\hline \multicolumn{6}{|c|}{--- POP (plants ha ${ }^{-1}$ ) --- } \\
\hline & \multicolumn{4}{|c|}{ 2015/16 Harvest } & \\
\hline Roundup Original $^{\circledR}$ & --- & 356875 & 356250 & 348750 & 351718 \\
\hline Roundup Ready ${ }^{\circledR}$ & --- & 373750 & 356875 & 373125 & 362187 \\
\hline Glyphotal $^{\circledR}$ & --- & 360000 & 352500 & 353750 & 352812 \\
\hline Roundup Transorb $^{\circledR}$ & --- & 356250 & 363125 & 363125 & 356875 \\
\hline Roundup $\mathrm{WG}^{\circledR}$ & --- & 359375 & 358125 & 366875 & 357343 \\
\hline Zapp QI ${ }^{\circledR}$ & --- & 358125 & 351250 & 358750 & 353281 \\
\hline Non glyphosate treated & --- & 347500 & 386875 & 366250 & 361406 \\
\hline Witness & & & 345000 & & \\
\hline \multirow[t]{2}{*}{ Means } & - & 358839 & 360714 & 361517 & 356517 \\
\hline & \multicolumn{4}{|c|}{ 2016/17 Harvest } & \\
\hline Roundup Original $^{\circledR}$ & 223750 & 223750 & 228125 & 246875 & $230625 \mathrm{~b}$ \\
\hline Roundup Ready ${ }^{\circledR}$ & 222500 & 201875 & 206875 & 246875 & $219531 \mathrm{~b}$ \\
\hline Glyphotal $^{\circledR}$ & 218750 & 225625 & 225625 & 245625 & $228906 \mathrm{~b}$ \\
\hline Roundup Transorb $^{\circledR}$ & 236875 & 254375 & 221250 & 235625 & $237031 \mathrm{a}$ \\
\hline Roundup $\mathrm{WG}^{\circledR}$ & 239375 & 218750 & 256875 & 246250 & $240312 \mathrm{a}$ \\
\hline Zapp QI $^{\circledR}$ & 221875 & 241250 & 247500 & 248125 & $239687 \mathrm{a}$ \\
\hline Non glyphosate treated & 208750 & 226250 & 224375 & 227500 & $221718 b$ \\
\hline Means & 224554 & 227411 & 230089 & 242411 & 231116 \\
\hline
\end{tabular}

Averages followed by the same letters within one column do not differ by the Scott-Knott test at $5 \%$ probability.

*: Means differ from the control by the Dunnett test at $5 \%$ probability.

The glyphosate formulations influenced plant size in both crops (Table 1). In general, in the first harvest, the formulations Glyphotal ${ }^{\circledR}$ and Roundup Transorb $^{\circledR}$ caused lower plant height (Table 4). In the second harvest, except for Zapp QI ${ }^{\mathbb{B}}$, lower heights were observed for all glyphosate formulations at a dose of 1.00 kg MC Extra ${ }^{\circledR}$. Furthermore, Zapp $\mathrm{QI}^{\circledR}$ provided linear increases in plant height at increasing doses (Figure 5). Reductions in size with the use of the biostimulant $(0.35$ $\mathrm{kg} \mathrm{ha}^{-1}$ dose) were observed with Roundup Ready ${ }^{\mathbb{B}}$ and Zapp QI ${ }^{\circledR}$. It should be noted that there was no adjustment for the other equations.

Table 4. Average values of plant height (AP) and insertion of the first pod (AIV) with the application of MC Extra ${ }^{\circledR}$ biostimulant with glyphosate formulations in a soybean culture.

\begin{tabular}{|c|c|c|c|c|c|}
\hline \multirow{2}{*}{ Glyphosate formulations } & \multicolumn{4}{|c|}{--- Doses MC Extra ${ }^{\circledR}\left(\mathrm{kg} \mathrm{ha}^{-1}\right)$--- } & \multirow{2}{*}{ Means } \\
\hline & 0.00 & 0.35 & 0.70 & 1.00 & \\
\hline \multicolumn{6}{|c|}{--- AP (cm) --- } \\
\hline \multicolumn{6}{|c|}{ 2015/16 Harvest } \\
\hline Roundup Original $^{\circledR}$ & --- & 83.4 & 84.7 & 82.3 & $83.7 \mathrm{a}$ \\
\hline Roundup Ready ${ }^{\circledR}$ & --- & 82.1 & 82.8 & 84.3 & $83.1 \mathrm{a}$ \\
\hline Glyphotal $^{\circledR}$ & --- & 76.5 & 77.9 & 75.7 & $78.4 \mathrm{~b}$ \\
\hline Roundup Transorb $^{\mathbb{R}}$ & --- & 76.2 & 76.1 & 73.9 & $77.4 \mathrm{~b}$ \\
\hline Roundup $\mathrm{WG}^{\circledR}$ & --- & 82.6 & 80.6 & 82.9 & $82.4 \mathrm{a}$ \\
\hline Zapp QI ${ }^{\circledR}$ & --- & 83.9 & 85.6 & 84.5 & $84.4 \mathrm{a}$ \\
\hline Non glyphosate treated & --- & 83.1 & 82.6 & 83.8 & $83.3 \mathrm{a}$ \\
\hline Witness & & & 83.4 & & \\
\hline Means & --- & 81.2 & 81.5 & 81.1 & 81.8 \\
\hline
\end{tabular}

Averages followed by the same letters in the column do not differ by the Scott-Knott test at $5 \%$ probability.

*: Means differ from the control by the Dunnett test at $5 \%$ probability. 
Table 4. Continuation.

\begin{tabular}{|c|c|c|c|c|c|}
\hline \multirow[t]{2}{*}{ Glyphosate } & \multicolumn{4}{|c|}{--- Doses MC Extra ${ }^{\circledR}(\mathrm{kg}$ ha-1) --- } & \multirow[t]{2}{*}{ Means } \\
\hline & 0.00 & 0.35 & 0.70 & 1.00 & \\
\hline \multicolumn{6}{|c|}{ 2016/17 Harvest } \\
\hline Roundup Original $^{\circledR}$ & $73.4 \mathrm{a}$ & $75.5 \mathrm{a}$ & $76.5 \mathrm{a}$ & $72.4 \mathrm{~b}$ & 73.7 \\
\hline Roundup Ready ${ }^{\circledR}$ & $71.0 \mathrm{a}$ & $66.5 \mathrm{~b}$ & $74.6 \mathrm{a}$ & $73.1 \mathrm{~b}$ & 70.9 \\
\hline Glyphotal $^{\circledR}$ & $70.8 \mathrm{a}$ & $70.4 \mathrm{a}$ & $69.1 \mathrm{a}$ & $73.2 \mathrm{~b}$ & 71.0 \\
\hline Roundup Transorb ${ }^{\circledR}$ & $73.1 \mathrm{a}$ & $72.6 \mathrm{a}$ & $73.2 \mathrm{a}$ & $70.6 \mathrm{~b}$ & 72.4 \\
\hline Roundup $\mathrm{WG}^{\circledR}$ & $71.6 \mathrm{a}$ & $72.5 \mathrm{a}$ & $71.5 \mathrm{a}$ & $72.7 \mathrm{~b}$ & 72.0 \\
\hline Zapp QI ${ }^{\circledR}$ & $71.1 \mathrm{a}$ & $66.8 \mathrm{~b}$ & $75.3 \mathrm{a}$ & $77.9 \mathrm{a}$ & 73.0 \\
\hline Non glyphosate treated & $74.4 \mathrm{a}$ & $74.1 \mathrm{a}$ & $74.2 \mathrm{a}$ & $70.1 \mathrm{~b}$ & 73.2 \\
\hline Means & 72.2 & 70.7 & 72.3 & 72.9 & 72.3 \\
\hline \multicolumn{6}{|c|}{--- AIV $(\mathrm{cm})$--- } \\
\hline \multicolumn{6}{|c|}{ 2015/16 Harvest } \\
\hline Roundup Original $^{\circledR}$ & --- & 16.7 & 14.5 & 15.7 & $15.2 \mathrm{~b}$ \\
\hline Roundup Ready ${ }^{\circledR}$ & --- & 17.9 & 17.2 & 16.2 & $15.3 \mathrm{a}$ \\
\hline Glyphotal $^{\circledR}$ & --- & 14.9 & 15.4 & 15.8 & $15.0 \mathrm{~b}$ \\
\hline Roundup Transorb ${ }^{\circledR}$ & --- & 15.6 & 13.4 & 13.7 & $14.2 \mathrm{~b}$ \\
\hline Roundup $\mathrm{WG}^{\circledR}$ & --- & 16.2 & 15.2 & 15.4 & $15.2 \mathrm{~b}$ \\
\hline Zapp QI ${ }^{\circledR}$ & --- & 15.8 & 17.8 & $22.2 *$ & $17.5 \mathrm{a}$ \\
\hline Non glyphosate treated & --- & 14.7 & 15.4 & 14.5 & $14.6 \mathrm{~b}$ \\
\hline Witness & & & 13.9 & & \\
\hline Means & --- & 16.0 & 15.6 & 16.2 & 15.4 \\
\hline \multicolumn{6}{|c|}{ 2016/17 Harvest } \\
\hline Roundup Original $^{\circledR}$ & 11.2 & 11.9 & 11.1 & 12.1 & 11.6 \\
\hline Roundup Ready ${ }^{\circledR}$ & 12.4 & 10.9 & 11.0 & 11.2 & 11.3 \\
\hline Glyphotal $^{\mathbb{B}}$ & 11.2 & 10.7 & 11.4 & 12.1 & 11.4 \\
\hline Roundup Transorb ${ }^{\circledR}$ & 11.6 & 11.0 & 10.8 & 11.2 & 11.1 \\
\hline Roundup $\mathrm{WG}^{\circledR}$ & 11.4 & 10.6 & 11.1 & 11.4 & 11.1 \\
\hline Zapp QI ${ }^{\circledR}$ & 11.8 & 11.7 & 10.8 & 10.9 & 11.3 \\
\hline Non glyphosate treated & 12.0 & 11.5 & 11.9 & 11.8 & 11.8 \\
\hline Means & 11.6 & 11.2 & 11.1 & 11.5 & 11.4 \\
\hline
\end{tabular}

Averages followed by the same letters in the column do not differ by the Scott-Knott test at $5 \%$ probability.

*: Means differ from the control by the Dunnett test at $5 \%$ probability.

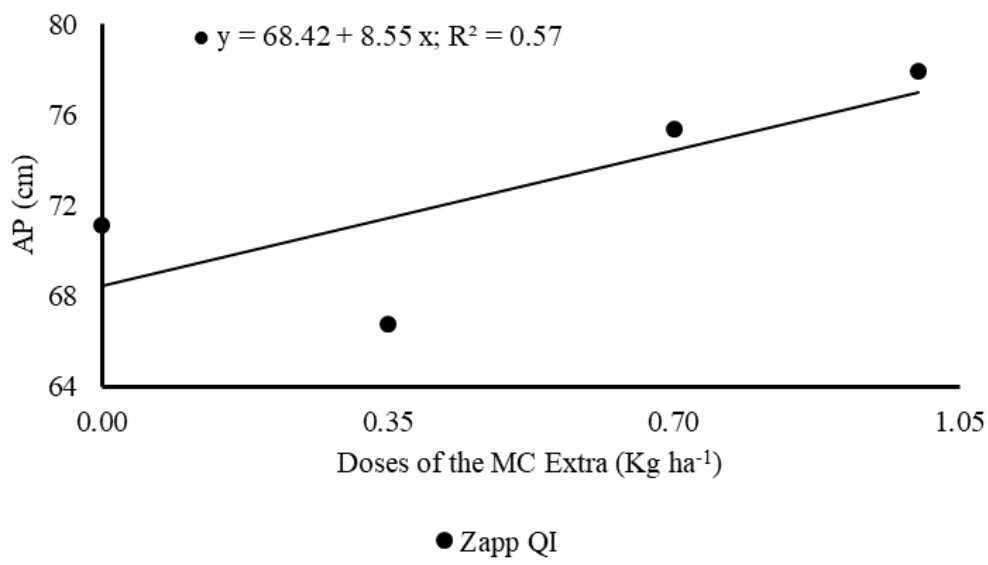

Figure 5. Unfolded values of plant height (AP) as a function of the doses of biostimulant $\mathrm{MC}$ Extra ${ }^{\circledR}$ in a soybean culture. 
Plant height is influenced by glyphosate application (ANDRADE et al., 2018) due to the inhibition of the EPSPS enzyme, responsible for catalyzing the condensation of shikimic acid (MEROTTO; WAGNER; MENEGUZZI, 2015). The reduction in the synthesis of this compound promotes a decrease in the synthesis of tryptophan, a precursor of the synthesis of indole acetic acid, a hormone responsible for cell division and multiplication (TAIZ et al., 2017). With the reduction in AIA synthesis, there will be a reduction in plant growth (CARVALHO, 2013) and a decrease in chlorophyll biosynthesis, photosynthetic rate, and the transport of photoassimilates in plants, impacting the formation of soybean yield components (BOTT et al., 2008).

In the 2015/16 crop, the doses of MC Extra ${ }^{\circledR}$ provided linear increases for the height of insertion of the first pod (Figure 6). Higher values were observed for the Roundup Ready ${ }^{\circledR}$ and Zapp QI ${ }^{\circledR}$ formulations (Table 4). In addition, there was a larger height of pod insertion in relation to the absolute control. Similar results were found for plant height and vigor for the Roundup Original $^{\circledR}$, Roundup Ready ${ }^{\circledR}$, Zapp QI ${ }^{\circledR}$, and MC Extra ${ }^{\circledR}$ formulations. In contrast, the formulations of Glyphotal ${ }^{\mathbb{R}}$ and Roundup Transorb ${ }^{\circledR}$ caused lower values of plant height, pod insertion, and vigor.

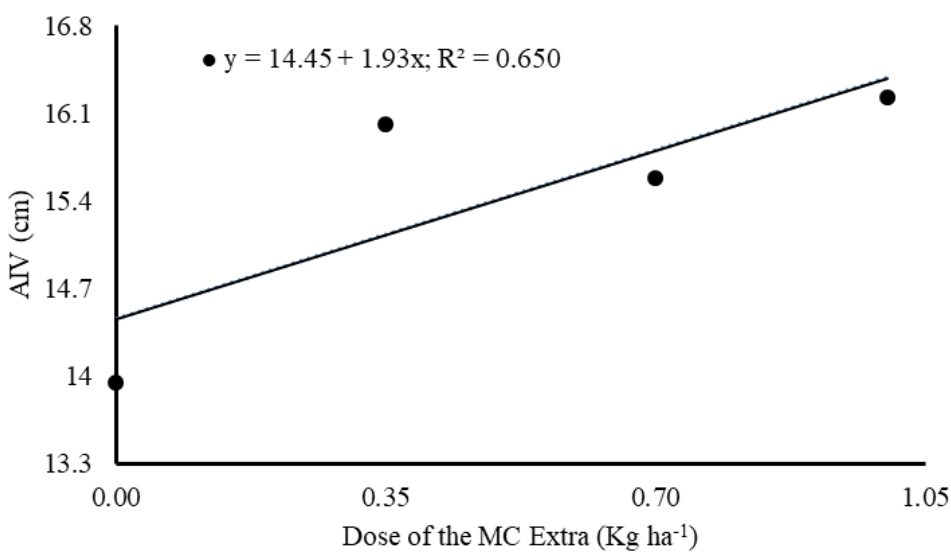

Figure 6. Mean values of height of insertion of the first pod (AIV) as a function of the doses of the biostimulant MC Extra $^{\circledR}$ in a soybean culture.

It is important to note that the positive response to the use of MC Extra ${ }^{\circledR}$ with glyphosate, regardless of the formulation in the 2016/17 crop, may be due to the fact that applications were performed on plants in a more early stage of development (four fully developed trifoliate leaves) in relation to the 2016/17 harvest. This leads us to infer that the sooner glyphosate is applied in the soy flowering stage, the more evident the repairing effect of MC Extra ${ }^{\circledR}$ when used together with glyphosate.

In addition, the habit of the semi-determined growth of cultivar TMG 7062 allowed the plants to continue growing by forming new trifoliate leaves after the appearance of the first inflorescences on the main stem. Thus, the more anticipated the application of the herbicide, as well as that of the biostimulant, the greater the recovery capacity of the soybean plant. This response is related to the stimulation of enzymatic activities and the growth of the root system through the use of MC Extra $^{\circledR}$, in which it is derived from algae extract and has the main effect of providing plants with a greater capacity for absorbing water and nutrients (VRIES; FEHR, 2011; MARTYNENKO et al., 2016).

Thus, the lower the toxic effect of the glyphosate formulation, the greater the synthesis of secondary metabolites and, consequently, the greater the size and production of photoassimilates by the plant. Once the greater amount of photoassimilates is transported to the grains, there is a greater weight of grains, which contributes to obtaining higher grain yields, as evidenced by the significant and positive correlations in both harvests (Table 5). 
Table 5. Pearson's linear correlation of plant height (AP) and first pod insertion (AIV), plant population (POP), number of grains per plant (NGP), thousand-grain-weight (PMG), and productivity variables of grain (PROD) with the application of the biostimulant MC Extra ${ }^{\circledR}$ with glyphosate formulations in a soybean culture.

\begin{tabular}{|c|c|c|c|c|c|}
\hline Characteristic & AIV & POP & NGP & PMG & PROD \\
\hline \multicolumn{6}{|c|}{--- 2015/16 Harvest --- } \\
\hline AP & 0.09 & -0.06 & 0.07 & 0.08 & 0.14 \\
\hline AIV & & 0.02 & 0.01 & -0.15 & -0.06 \\
\hline POP & & & $-0.80 * *$ & $0.27 * *$ & 0.07 \\
\hline NGP & & & & $-0.33 * *$ & $0.39 * *$ \\
\hline PMG & & & & & $0.45 * *$ \\
\hline \multicolumn{6}{|c|}{---2016/17 Harvest --- } \\
\hline AP & -0.15 & 0.13 & -0.07 & -0.06 & 0.04 \\
\hline AIV & & 0.00 & 0.01 & 0.08 & 0.07 \\
\hline POP & & & $-0.82 *$ & -0.14 & 0.06 \\
\hline NGP & & & & 0.33 & $0.44 * *$ \\
\hline PMG & & & & & $0.25^{* *}$ \\
\hline
\end{tabular}

**, *: Significant at 1 and 5\% probability by $t$ test.

The above results reflect the beneficial effect of the biostimulant MC Extra ${ }^{\circledR}$, at the dose of $0.35 \mathrm{~kg} \mathrm{ha}^{-1}$, on grain yield. However, the joint use with glyphosate makes it necessary to increase the biostimulant dose when the objective is to obtain higher grain yields. Different responses of the formulations were observed for productivity and its components as well as plant size which proves the need to know the effects of biostimulants on soybean cultures.

\section{CONCLUSION}

The efficient dose of MC Extra ${ }^{\circledR}$ depends on the formulation of glyphosate.

The associations of the dose of $1.00 \mathrm{~kg} \mathrm{ha}^{-1}$ of MC Extra ${ }^{\circledR}$ with the formulations Roundup Original ${ }^{\circledR}$, Roundup Ready ${ }^{\circledR}$, and Roundup Transorb ${ }^{\circledR}$ were the most promising for obtaining higher soybean grain yields.

Regardless of the MC Extra ${ }^{\circledR}$ dose, no increase in grain yield was found with use in conjunction with Roundup $\mathrm{WG}^{\circledR}$ and Zapp Qi ${ }^{\circledR}$.

The cultivar TMG 7062 IPRO $^{\circledR}$ responded to a dose of $0.35 \mathrm{~kg} \mathrm{ha}^{-1}$ of MC Extra ${ }^{\circledR}$ with increased grain productivity; however, when adding glyphosate, biostimulant doses had to be increased to obtain higher grain yields.

\section{REFERENCES}

AGROFIT, AGROFIT. Sistema de agrotóxicos fitossanitários. Ministério da Agricultura Pecuária e Abastecimento, 2012.

ANDRADE, C. L. L. et al. Bioestimulantes derivados de Ascophyllum nodosum associados ao glyphosate nas características agronômicas da soja $\mathrm{RR}^{\circledR}$. Revista Brasileira de Herbicidas, 17: e592, 2018 .

BINSFELD, J. A. et al. Uso de bioativador, bioestimulante e complexo de nutrientes em sementes de soja. Pesquisa Agropecuária Tropical, 44: 88-94, 2014.

BOMTEMPO, A. F. et al. Influência de bioestimulantes e nutrientes na emergência e no crescimento inicial de feijão, soja e milho. Revista Brasileira de Milho e Sorgo, 15: 86-93, 2016.

BOTT, S. et al. Glyphosate-induced impairment of plant growth and micronutrient status in glyphosate-resistant soybean (Glycine max L.). Plant Soil, 312: 185-194, 2008.

CARVALHO, L. B. Herbicidas. 1. ed. Lages, SC: EDITADO PELO AUTOR, 2013. 62 p.

COBB, A. H.; READE, J. P. H. Herbicides and Plant Physiology. 2a . ed. London: Wiley-Blackwell, 2010. 296 p.

CRAIGIE, J. S. Seaweed extract stimuli in plant science and agriculture. Journal of Applied Phycology, 23: 371-393, 2011.

DU JARDIN, P. Plant biostimulants: Definition, concept, main categories and regulation. Scientia Horticulturae, 196: 3-14, 2015.

MACKINNON, S. L. et al. Improved methods of analysis for betaines in Ascophyllum nodosum and its commercial seaweed extracts. Journal of Applied 
Phycology, 22: 489-494, 2010.

MARTINS, D. et al. Ação de adjuvantes na absorção e translocação de glyphosate em plantas de aguapé (Eichhornia crassipes). Planta Daninha, 27: 155163, 2009.

MARTYNENKO, A. et al. Thermal imaging of soybean response to drought stress: the effect of Ascophyllum nodosum seaweed extract. Springerplus, 5:1393, 2016.

MEROTTO JR., A.; WAGNER, J.; MENEGUZZI, C. Effects of Glyphosate and foliar application of micronutrients in 39 transgenic soybean. Bioscience Journal, 31: 499-508, 2015.

OSIPE, J. B. et al. Seletividade de aplicações combinadas de herbicidas em pré e pós-emergência para a soja tolerante ao glyphosate. Bioscience Journal, 30, 623631,2014

PETTER, F. A. et al. Effect of glyphosate and water stress on plant morphology and nutrient accumulation in soybean. Australian Journal of Crop Science, 10: 251-257, 2016.

PINTO, C. C. et al. Effect of dosage and times of application of glyphosate on yield and qualitative in soybean RR. Revista de Ciências Agrárias, 39: 310 $-317,2016$.

POVERO, G. et al. Systematic approach to discover and characterize natural plant biostimulants. Frontiers in Plant Science, 7: 1-9, 2016.

PROCÓPIO, S. O. et al. Plantio cruzado na cultura da soja utilizando uma cultivar de hábito de crescimento indeterminado. Revista de Ciências Agrárias, 56: 319-325, 2013.

SANTOS, A. A. M. et al. Substância húmica na redução da fitotoxidade dos herbicidas Roundup Ready + Lactofen na cultura da soja. Revista Tecnologia \& Ciência Agropecuária, 9: 35-41, 2015.

SHARMA, H. S. S. et al. Plant biostimulants: a review on the processing of macroalgae and use of extracts for crop management to reduce abiotic and biotic stresses. Journal of Applied Phycology, 26: 465-490, 2014.

SILVA, A. G. et al. Inoculação de sementes de milho safrinha com Azospirillum e aplicação de nitrogênio em cobertura. Revista Brasileira de Milho e Sorgo, 14: 358-370, 2016.

TAIZ, L. et al. Fisiologia e desenvolvimento vegetal. 6. ed. Porto Alegre, RS: ARTMED, 2017.
$888 \mathrm{p}$.

TANDON, S.; DUBEY, A. Effects of Biozyme (Ascophyllum nodosum) biostimulant on growth and development of soybean [Glycine $\max$ (L.) Merill]. Communications in Soil Science and Plant Analysis, 46: 845-858, 2015.

VAN OOSTEN, M. J. et al. The role of biostimulants and bioeffectors as alleviators of abiotic stress in crop plants. Chemical and Biological Technologies in Agriculture, 4: 1-12, 2017.

VIEIRA, B. C. et al. Influence of airspeed and adjuvants on droplet size distribution in aerial applications of glyphosate. Applied Engineering in Agriculture, 34: 507-513, 2018.

VELINI, E. D. et al. Glyphosate uso Sustentável. Botucatu, SP: FEPAF, 2012. 202 p.

VRIES, B. D.; FEHR, W. R. Impact of the event for glyphosate tolerance on agronomic and seed traits of soybean. Crop Science, 51: 1023-1027, 2011.

WALLY, O. S. D. et al. Regulation of phytohormone biosynthesis and accumulation in Arabidopsis following treatment with commercial extract from the marine macroalga Ascophyllum nodosum. Journal of Plant Growth Regulation, 32: 324-339, 2013.

ZOBIOLE, L. H. S.; KREMER, R. J.; CONSTANTIN, J. Glyphosate effects on photosynthesis, nutrient accumulation, and nodulation in glyphosate $\square$ resistant soybean. Journal of Plant Nutrition and Soil Science, 175: 319-330, 2012. 